\title{
The Implementation of Literary Works in Teaching Literary Translation
}

Sylvie Meiliana,

Department of English Literature, Faculty of Language and Literature, Universitas Nasional, Jakarta

sylvie.meiliana@civitas.unas.ac.id

Article History: $\quad$ Received: June $12^{\text {th }} 2020$

Revised: August 13th, 2020

Accepted: September 30th, 2020

\begin{abstract}
This reseach aims to show the implementation of literary works in literary translation by giving way to implement the literary work in revealing cultural terms found in a literary work, namely Achmad Tohari's Ronggeng Dukuh Paruk Novel. Based on the literary work, the research on literary translation is done by investigating the translation procedure applied in translating the cultural terms from Indonesian into English. This research used a descriptive qualitative method with a content analysis technique done by taking the flow model followed by data reduction, data presentation, and conclusion-the analysis used semantic approach and Peter Newmark's translation procedures. The result of the research shown by implementing literary work, the research of literary translation reveals that there are 16 cultural terms and classified in 6 different categories: musical instruments, clothes, accessories, work and leisure, activities and procedures, and religious terms. In translating the novel, there are 7 translation precedures used by the translator: transference, naturalization, cultural equivalent, functional equivalent, descriptive equivalent, couplets, and notes.
\end{abstract}

Keywords: Literary works, implementation, literary Translation, Translation procedures, cultural terms.

\section{INTRODUCTION}

Translation is a process to translate or render one source language into another target language. Besides, Hatim and Munday stated that translation has at least two definitions; Translation is as a process and a product. The former focuses on the role of translator in taking source text and translating it into target text. In contrast, translation as a product is emphasized in the product text. Catford had concluded years ago when he stated that translation is "the replacement of textual material in one language (SL) by equivalent textual material in another language (TL)." From the views above, it can be said that translation can be defined as a process as well as a product of translation activity in which render source text into 
equivalent target text.(Sundari, 2016)

Translation plays an important role in bridging the gaps between the different cultures and nations. Literary translations in particular help these different nations reach a universal culture on a common ground. A good translation is not simply concerned with transferring the propositional content of the source language text (SLT), but also its other pragmatic features. (Hasan, 2011:1)

Literary Translation is a Translation type where the source data are literary works such as prose and poetry. The translation of literature is fundamentally different from other categories. This is because the main principle of literary translation is the dominance of poetic communicative function. It means that in addition to rendering information to the reader, literary translation also has aesthetic functions. The artistic image of a character or nature created in a particular literary work will certainly impact the reader. For this reason the literary translator should take into account specific features of the text. The poetic focus of the text makes this type of translation different from texts of an informative type. Devy (in Hasan, 2011:2) stated that literary translation is a type of translation that is distinguished from translation in general. A literary translation must reflect the imaginative, intellectual and intuitive writing of the author. In fact, literature is distinguished by its aesthetics. Little concern has been devoted to the aesthetics of literary translations because these translations are popularly perceived as unoriginal

As its name suggests, literary translation refers to translation done for literature such as poems, plays, short stories, and novels. Just as general translation is the simplest form and legal translation is the most difficult form, many people consider literary translation as the highest form of translation. The reason behind this is because literary translation goes beyond mere translation of context; a literary translator must be proficient in translating humor, cultural nuances, feelings, emotions, and other subtle elements of a given work.

According to Newmark (1988: 94), the concept of culture is the way of life and its manifestations that are peculiar to community that uses a particular language as its means of expression. Culture is a totality of science and perception mastery, and is related to behaviour and certain events within society. Culture has particular norms which are obeyed by society and is related to language. Essentially, culture includes the system of thoughts, concepts, rules, and meanings that underlie it and revealed in humans' way of life. (Newmark in Kuswahono, 2019)

In teaching literary Translation, Zang Yan (2016) stated that teachers should handle the relationship between translation theories and practice appropriately. Translation theories and practice are the same important aspects in learning and teaching translation. Teachers ought to teach translation skills as well as 
translation theories. Some teachers think that practice is the only way to translate learning and then neglect that the authentic theories have instructive function to translation practice. Usually, it is planned that translation teaching should be conducted after language learning. Although students have already had the foundation of basic language abilities, they have never learnt the translation theories or skills systematically. The translation abilities they have are the accumulation of perceptive knowledge. In ancient or at present, numerous translators or theorists have left us so many priceless theories concerning various aspects of translation. If students learnt those theories, which were extracted from the former practice by others, and use them appropriately, their translation ability would be improved rapidly. Translator equipped with theoretical knowledge is more flexible in method and clearer in purpose of translation than who knows nothing about theory.

Teacher should offer students a general comprehension of the history and development of translation theories, give them some ideas of the new achievement or trend in the theoretical research, such as Engine. A. Nidet's equivalence of response, Tytler's translation principles, Roman Jacobson's three divisions of translation, etc. Translation is such a complicated process that there are many debates in translation studies. But the goal of teaching translation in second language learning class is making students familiar with the basic theories about literary translation. Holding this aim of teaching, teachers could decide how to introduce theories in class. Under the instruction of literary translation theories, translation practice is necessary because it makes students understand theories well. (Zhang Yan, 2016)

On the other hand, literature translation is a creative process. Students' practice should not be bounded or controlled by any theory. When commentating on student's translation, teacher should not take a reference translation as a standard translation. Reference translation is just a referential material. As a creative activity, the results of translation are reasonable to be different. (Zhang Yan, 2016)

\section{METHOD}

This study applied descriptive qualitative method with content analysis technique done by taking the flow model followed by data reduction, data presentation, and conclusion. Bogdan and Taylor (in Moleong, 2013:3) suggested that qualitative procedures would result in research that reveals qualitative data with an approach aimed at holistic background and at individuals or at perceiving as a whole. Miles (in Meiliana, 2019) determines qualitative steps in research as 1) data collection; 2) data reduction; 3) data display; 4) drawing and verifying conclusions. This study focuses on the cultural terms in the novel "Ronggeng Dukuh Paruk" by Ahmad Tohari and translated into "The Dancer" by Rene 
T.A.Lysloff.

Newmark (in Hapsari, 2013) associated cultural word with a particular language and cannot be literally translated. Newmark defined culture as the way of life and its manifestation that is very special to a community that uses certain language as the way of expression. He classifies cultural words into several terms. First is ecology which consists of geographical features that are usually value-free, politically and commercially, and normally distinguished from other cultural terms. Second is material culture that involves food, clothes, houses and towns and transport. Third is social culture - work and leisure. Fourth is organizations, customs, activities, procedures, concepts. Fifth are gestures and habits.

In the process of translating cultural words, some procedures of translation to render meaning in SL into TL properly were needed. Therefore, translation procedure can be assumed as a set of method or technique in transferring the meaning from SL to TL. According to Newmark (in Krisnawati, 2017), translation procedure is the translator's ways for translating SL (words, phrase, terminologies, text) into TL.

They are eighteen procedure proposed by Newmark, they are (1) Transference, the translations process of transferring the foreign word from SL to TL without any change at all. (2) Naturalization . the translations procedure that adapts the SL word first to the normal pronunciation and then to the normal morphology. (3) Cultural Equivalent, the translation procedure in translating a cultural word in the SL with a TL cultural word. (4) Functional equivalent, the translation procedure that translates a word in the SL with a functional equivalent TL words. This procedure is applied for cultural words that require the use of culture-free word or sometimes with a new specific term. (5) Descriptive equivalent, the translation procedure that uses description in translating SL to TL. (6) Synonymy, the translation procedure that uses word in SL which has the nearest equivalent in the TL. (7) Through translation, the translation procedure for translating common collocations, organizations' names, the components of compounds and phrases. (8) Transposition, a translation procedure involving a change in the grammar form SL to TL. (9) Modulation, the translation procedure which changes the point of view from the SL to the TL. (10) Recognized translation, the translation procedure that translates the accepted translation of any institutional term. (11) Reduction and Expansion, translation procedure used by the translator to add or omit elements in translation. (12) Paraphrase, the translation procedure whereby the translator replaces a word in the SL by a group of words or an expression in the TL. (13) Literal translation, translating the SL to the TL by word per word technique. Normally, literal translation should be used only when they are already recognized terms. (14) Couplet, a translation procedure that uses more than one procedure to deal with single problem. (15) Compensation is a translation procedure whereby the translator solves the SL 
problem that cannot take the same form in the TL by replacing then aspects with other elements or forms in the SL. (16) Note that the translation procedure that inserts additional information a translator may have to add to his TL version from SL. (17) Componential analysis, the translation procedure that comperes a SL word with a TL word which has a similar meaning but it is not an obvious equivalent by demonstrating first their common and then their differing sense components. (18) Generalization and Particularization, the translation procedure which translate the SL to TL either to have more general or specific meaning.

\section{RESULTS AND DISCUSSION}

There are six categories of cultural terms used in the novel, they are musical instruments, clothes, accessories, work and leisure, activities and procedures, and religious terms.

\section{Musical instruments.}

\begin{tabular}{|c|c|c|}
\hline Musical instrument & Source Language & Target Language \\
\hline Gendang & $\begin{array}{l}\text { Ketika sinar matahari } \\
\text { mulai meredup di langit } \\
\text { barat, Srintil menari } \\
\text { dan bertembang. } \\
\text { Gendang, gong dan } \\
\text { calung turut } \\
\text { mengiringinya. Rasus } \\
\text { bersila, menepak-nepak } \\
\text { lutut menirukan gaya } \\
\text { seorang penggendang. } \\
\text { (Tohari, 2003: 6) }\end{array}$ & $\begin{array}{l}\text { As the sunshine grew hazy } \\
\text { into the western sky, Srintil } \\
\text { danced and sang, } \\
\text { accompanied by the } \\
\text { vocalized sounds of drum, } \\
\text { blown gong, and xylophone. } \\
\text { Rasus sat on the ground, his } \\
\text { legs crossed, slapping his } \\
\text { knees to imitate the } \\
\text { movements of a drummer. } \\
\text { (Lysloff, 2003: 7-8) }\end{array}$ \\
\hline
\end{tabular}

The word gendang in translated into drum that is the closest meaning similar to the gendang itself. The translator used functional equivalent procedure to translate the word gendang into drum. The procedure includes the Translation of the SL into a cultural-free word that can be found in the TL.

\begin{tabular}{|l|l|l|}
\hline Musical instrument & Source Language & Target Language \\
\hline calung & $\begin{array}{l}\text { "Wah, jadi kalau } \\
\text { begitu," jawab Rasus } \\
\text { cepat. "Aku akan } \\
\text { menirukan calung dan } \\
\text { Darsun menirukan gong } \\
\text { tiup.Hayo!" (Tohari, } \\
2003: 12)\end{array}$ & $\begin{array}{l}\text { "Well in that case," } \\
\text { answered Rasus quickly," } \\
\text { I'll be the drum. Warta dan } \\
\text { be the calung zylophone } \\
\text { and Darsun the blown gong, } \\
\text { Let's go!" (Lysloff, 2003:7) }\end{array}$ \\
& & \\
\hline
\end{tabular}




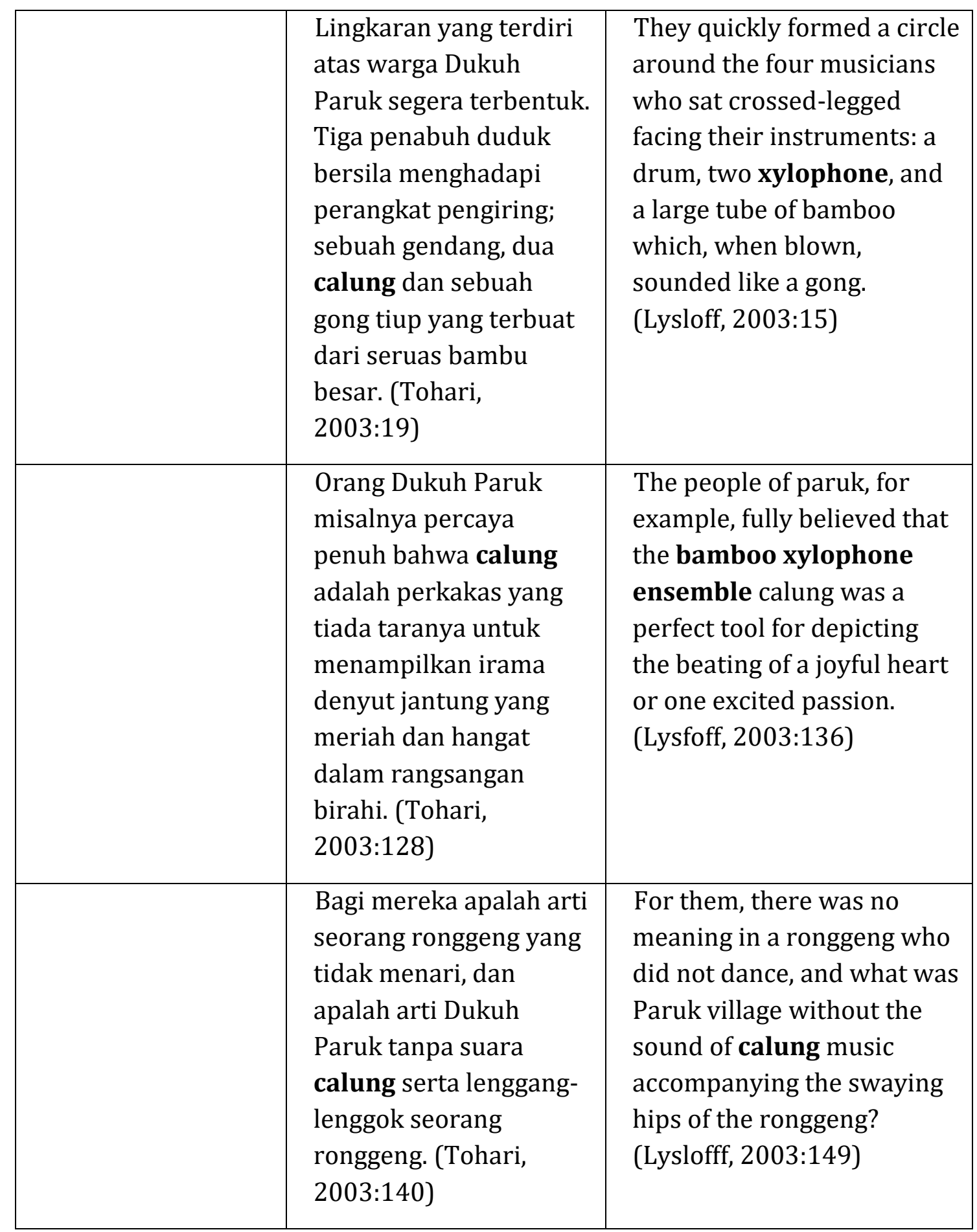

In the first data, the translation procedure used is couplets. This procedure involves the use of two different procedures. In this case, the translator used both the naturalization and the functional equivalent procedures. In the second data, the translator used the functiona equivalent procedures which involves the use of a cultural-free word in the TL to replace the actual word in the SL. In the third data, calung is translated into bamboo xylophone ensemble calung using both the naturalization and notes procedures. This translation is done by keeping the 
original spelling of calung and adding the additional information "bamboo xylophone ensemble". In the fourth data, calung is written in the same spelling in the $\mathrm{TL}$, using the naturalization procedure. This procedure requires the use of the existing word in the SL to be in the TL.

\begin{tabular}{|c|c|c|}
\hline Musical instrument & Source Language & Target Language \\
\hline Gong Tiup & $\begin{array}{l}\text { "Wah, jadi kalau } \\
\text { begitu," jawab Rasus } \\
\text { cepat. "Aku akan } \\
\text { menirukan bunyi } \\
\text { gendang. Warta } \\
\text { menirukan calung dan } \\
\text { Darsun menirukan } \\
\text { gong tiup. Hayo!" } \\
\text { (Tohari, 2003:12) }\end{array}$ & $\begin{array}{l}\text { "Well in that case," } \\
\text { answered Rasus qucikly," } \\
\text { I'll be the drum. Warta can } \\
\text { be the calung xylophone } \\
\text { and Darsun the blown } \\
\text { gong, Let's go!" (Lysloff, } \\
2003: 7 \text { ) }\end{array}$ \\
\hline
\end{tabular}

In this translation, the transference procedure is applied to translate the word gong tiup into blown gong. The word gong itself is recognizable by the TL, but the word tiup needed to be translated into blown in the TL.

\section{Clothes}

\begin{tabular}{|c|c|c|}
\hline Clothes & Source Language & Target Language \\
\hline \multirow[t]{2}{*}{ Sampur } & $\begin{array}{l}\text { "Ya. Dan tentu sampean } \\
\text { perlu memperhalus } \\
\text { tarian Srintil. Cucuku } \\
\text { tampaknya belum } \\
\text { pintar melempar } \\
\text { sampur. Nah, ada lagi } \\
\text { yang penting; masalah } \\
\text { 'rangkap' tentu saja. Itu } \\
\text { urusanmu, bukan? } \\
\text { (Tohari, 2003:16) }\end{array}$ & $\begin{array}{l}\text { "Yeah, and of course you'll } \\
\text { need to refine Srintil's } \\
\text { dancing. She seems to be } \\
\text { having trouble flipping her } \\
\text { scarf properly. And, there's } \\
\text { another thing: the problem } \\
\text { of rangkep, of course. That's } \\
\text { right up your alley, isn't?" } \\
\text { (Lysfoff, 2003:12) }\end{array}$ \\
\hline & $\begin{array}{l}\text { Di dalam rumah, Nyai } \\
\text { Kartareja sedang } \\
\text { merias Srintil. } \\
\text { Tubuhnya yang kecil } \\
\text { dan masih lurus } \\
\text { tertutup kain sampai ke } \\
\text { dada. Angkinnya } \\
\text { kuning. Di pinggang kiri } \\
\text { kanan ada sampur }\end{array}$ & $\begin{array}{l}\text { In the Kartareja house, } \\
\text { Srintil was being adorned in } \\
\text { a ronggeng dancer's style by } \\
\text { Mrs. Kartareja. Her small } \\
\text { thin body was covered to } \\
\text { her chest with a wrap- } \\
\text { around batik kain held close } \\
\text { with a yellow waistband. A } \\
\text { bright orange sash hung }\end{array}$ \\
\hline
\end{tabular}




\begin{tabular}{|l|l|l|}
\hline & $\begin{array}{l}\text { berwarna merah saga. } \\
\text { (Tohari, 2003:18) }\end{array}$ & $\begin{array}{l}\text { loosely from each side of } \\
\text { her hips. (Lysloff, 2003:14) }\end{array}$ \\
\hline $\begin{array}{l}\text { Sulam, Lurah Pecikalan } \\
\text { atau bahkan Bapak } \\
\text { Siten Wedana adalah } \\
\text { sebagian kecil deretan } \\
\text { nama laki-laki yang } \\
\text { runduk di bawah } \\
\text { kibasan sampur Srintil. } \\
\text { (Tohari, 2003:114) }\end{array}$ & $\begin{array}{l}\text { Sulam, the chief of } \\
\text { Pecikalan Village, and even } \\
\text { Mr. Assistant District } \\
\text { Administrator were just two } \\
\text { of a long line of men who } \\
\text { had succumbed to the flick } \\
\text { of Srintil's dance scarf. } \\
\text { (Lysfoff, 2003:120) }\end{array}$ \\
\hline
\end{tabular}

In the first, second, and third data, the procedure used is the functional equivalent procedure as sampur is translated into scarf, sash, and dance scarf. The translator wanted to show the variety of words used within the translated novel equal to the storyline.

\begin{tabular}{|c|c|c|}
\hline Clothes & Source Language & Target Language \\
\hline Kain & $\begin{array}{l}\text { Di dalam rumah, Nyai } \\
\text { Kartareja sedang } \\
\text { merias Srintil. } \\
\text { Tubuhnya yang kecil } \\
\text { dan masih lurus } \\
\text { tertutup kain sampai } \\
\text { ke dada. Angkinnya } \\
\text { kuning. Di pinggang kiri } \\
\text { kanan ada sampur } \\
\text { berwarna merah saga. } \\
\text { (Tohari, 2003:18) }\end{array}$ & $\begin{array}{l}\text { In the Kartareja house, } \\
\text { Srintil was being adorned in } \\
\text { the style of a ronggeng } \\
\text { dancer by Mrs. Kartareja. } \\
\text { Her small thin body was } \\
\text { covered to her chest with a } \\
\text { wrap-around batik kain } \\
\text { held close with a yellow } \\
\text { waistband. A bright orange } \\
\text { sash hung loosely from each } \\
\text { side of her hips. (Lysloff, } \\
\text { 2003:14) }\end{array}$ \\
\hline
\end{tabular}

The translator used the descriptive equivalent procedure to translate kain into a wrap-around batik kain. This procedure is used to elaborate some aspects to the reader in term of the SL including form and function.

\begin{tabular}{|c|c|c|}
\hline Clothes & Source Language & Target Language \\
\hline Angkin & $\begin{array}{l}\text { Tubuhnya yang kecil } \\
\text { dan masih lurus } \\
\text { tertutup kain sampai ke } \\
\text { dada. Angkinnya } \\
\text { kuning. Di pinggang kiri } \\
\text { kanan ada sampur } \\
\text { berwarna merah saga. }\end{array}$ & $\begin{array}{l}\text { Her small thin body was } \\
\text { covered to her chest with a } \\
\text { wrap-around batik kain } \\
\text { held close with a yellow } \\
\text { waistband. A bright orange } \\
\text { sash hung loosely from each } \\
\text { side of her hips. (Lysloff, }\end{array}$ \\
\hline
\end{tabular}


(Tohari, 2003:18)

2003:14)

The functional equivalent is the procedure used to translate the word angkin into waistband. This equivalent needs a cultural free-word applied in the TL. The word angkin is translated into waistband because the TL has the same function as the SL.

\begin{tabular}{|l|l|l|}
\hline Clothes & Source Language & Target Language \\
\hline Setagen & Megap-megap, & Gasping for air, she opened \\
& mulutnya terbuka & her mouth like a fish. She \\
& seperti ikan mujair. Dan & stared wide-eyed seeing \\
& terbelalak karena & that her sash and camisole \\
setagen dan kutangnya & had been opened. (Lysloff, \\
& sudah terbuka. (Tohari, & 2003: 210) \\
& $2003: 194)$ & \\
\hline
\end{tabular}

This translation uses the functional equivalent procedure because the TL uses the cultural free-word to replace the TL's cultural word. Setagen is translated into sash because of its similar function.

\section{Accessories}

\begin{tabular}{|l|l|l|}
\hline Accessories & Source Language & Target Language \\
\hline Konde & $\begin{array}{l}\text { "Lihat, kondenya } \\
\text { terlalu tinggi, kan?" } \\
\text { (Tohari, 2003:186) }\end{array}$ & $\begin{array}{l}\text { “Don't you think that her } \\
\text { hair is tied up too high? } \\
\text { (Lysloff, 2003:201) }\end{array}$ \\
\hline
\end{tabular}

In translating konde into hari is tied up, the translator used descriptive equivalent procedure.

\begin{tabular}{|l|l|l|}
\hline Accessories & Source Language & Target Language \\
\hline Susuk & $\begin{array}{l}\text { ‥ yang dimaksud oleh } \\
\text { Sakarya tentulah soal } \\
\text { guna-guna, pekasih, } \\
\text { susuk ... (Tohari, } \\
2003: 16)\end{array}$ & $\begin{array}{l}\text { Sakarya was referring to the } \\
\text { black magic, love charms, } \\
\text { body piercing with } \\
\text { talismans ... (Lysloff, } \\
\text { 2003:12) }\end{array}$ \\
\hline Beberapa susuk emas \\
$\begin{array}{l}\text { dipasang oleh Nyai } \\
\text { Sakarya di tubuh Srintil } \\
\text { (Tohari, 2003:19) }\end{array}$ & $\begin{array}{l}\text { Mrs. Kartareja had also } \\
\text { inserted several gold } \\
\text { talismans under Srintil's } \\
\text { skin/ (Lysloff, 2003:12) }\end{array}$ \\
\hline
\end{tabular}

In the first data, the translator used descriptive equivalent procedure and in the second data, functional equivalent procedure was used. Susuk is related to magic, while body piercing is related to body accessories or decoration.Both terms 
are different, but combining the two terms has resulted in a phrase that well described both function and usage.

4. Work and Leisure

\begin{tabular}{|c|c|c|}
\hline Work and Leisure & Source Language & Target Language \\
\hline Ronggeng & $\begin{array}{l}\text { "Dukuh Paruk tanpa } \\
\text { ronggeng, bukanlah } \\
\text { Dukuh Paruk. Srintil, } \\
\text { cucuku sendiri, akan } \\
\text { mengembalikan citra } \\
\text { sebenarnya pedukuhan } \\
\text { ini, " (Tohari, 2003: 15) }\end{array}$ & $\begin{array}{l}\text { "Paruk Village without a } \\
\text { ronggeng dancer isn't } \\
\text { Paruk Village. Srintil, my } \\
\text { own granddaughter, will } \\
\text { bring back the true } \\
\text { greatness of this village." } \\
\text { (Lysloff, 2003:11) }\end{array}$ \\
\hline
\end{tabular}

In doing the translation ronggeng becomes ronggeng dancer, the translator used the functional equivalent procedure. The translator used the term ronggeng dancer to emphasize the type of dance performed.

\begin{tabular}{|c|c|c|}
\hline Work and Leisure & Source Language & Target Language \\
\hline Dukun Ronggeng & $\begin{array}{l}\text { Keesokan harinya } \\
\text { Sakarya menemui } \\
\text { Kartareja. Laki-laki } \\
\text { yang hampir sebaya ini } \\
\text { secara turun-temurun } \\
\text { menjadi dukun } \\
\text { ronggeng di Dukuh } \\
\text { Paruk. (Tohari, } \\
\text { 2003:16) }\end{array}$ & $\begin{array}{l}\text { The following day, Sakarya } \\
\text { went to visit Kartareja, a } \\
\text { man his own age who, } \\
\text { through inheritance, had } \\
\text { become the village dukun } \\
\text { for ronggeng. (Lysloff, } \\
2003: 11 \text { ) }\end{array}$ \\
\hline & $\begin{array}{l}\text { Sekarang jawab } \\
\text { pertanyaanku; bisakah } \\
\text { kalian membawa Srintil } \\
\text { kemari sekarang juga? } \\
\text { Kalau tidak, mampus } \\
\text { saja. Jangan coba-coba } \\
\text { menjadi dukun } \\
\text { ronggeng!" (Tohari, } \\
\text { 2003:121) }\end{array}$ & $\begin{array}{l}\text { Just answer my question: } \\
\text { Are you going to bring } \\
\text { Srintil here or not? If not, to } \\
\text { hell with you. Just don't } \\
\text { pretent to be ronggeng } \\
\text { trainer!" (Lysloff, } \\
\text { 2003:128) }\end{array}$ \\
\hline
\end{tabular}

In the first data, the translator did' $t$ change the dukun. This mainly has something to do by preserving the actual context of the story. In the second data, dukun ronggeng is translated into ronggeng trainer. Based on both of the data, the procedures of naturalization and functional equivalent used by the translator. 


\begin{tabular}{|l|l|l|}
\hline Work and Leisure & Source Language & Target Language \\
\hline Gendak & $\begin{array}{l}\text { Kemudian menyusul } \\
\text { celoteh spekulasi; } \\
\text { gendak Srintil kali ini } \\
\text { adalah si Anu atau } \\
\text { Bapak Anu, pangkatnya } \\
\text { ini atau kerbaunya } \\
\text { sekian belas. (Tohari, } \\
\text { 2003:125) }\end{array}$ & $\begin{array}{l}\text { And then, afterwards, they } \\
\text { would gossip about who her } \\
\text { current lovers might be and } \\
\text { how rich they were. } \\
\text { (Lysloff,2003:132) }\end{array}$ \\
\hline
\end{tabular}

In translating gendak into lovers, the translator wanted to describe that the kind of relationship is done outside marriage as a sexual partner. This kind of translation procedure is called cultural equivalent because the culture of the TL has the closesst meaning to the SL.

\begin{tabular}{|l|l|l|}
\hline Work and Leisure & Source Language & Target Language \\
\hline Gowok & $\begin{array}{l}\text { "Lha iya. Ini uang untuk } \\
\text { panjer meronggeng. } \\
\text { Dan ini buat panjer } \\
\text { menjadi gowok. Ambil } \\
\text { semua, tetapi nyatakan } \\
\text { dulu kesanggupan } \\
\text { advance for a performance } \\
\text { and for your work as a } \\
\text { gowok. You can have it all if } \\
\text { 2003:201) }\end{array}$ & $\begin{array}{l}\text { "Tou're willing to do both." } \\
\text { (Lysloff, 2003:220) }\end{array}$ \\
& & \\
\hline
\end{tabular}

This translation used a naturalization procedure because the translator kept the SL term the sama as the TL.

\section{Activities and Procedures}

\begin{tabular}{|l|l|l|}
\hline $\begin{array}{l}\text { Activities and } \\
\text { Procedures }\end{array}$ & Source Language & Target Language \\
\hline Tayub & $\begin{array}{l}\text { "Aku akan } \\
\text { menyelenggarakan } \\
\text { tayub , Kang," kata } \\
\text { Sentika mengawali } \\
\text { bicaranya. (Tohari, } \\
\text { 2003:209) }\end{array}$ & $\begin{array}{l}\text { "I'd like to organize social } \\
\text { dancing with the } \\
\text { ronggeng," said Sentika, } \\
\text { opening up the discussion. } \\
\text { (Lysloff, 2003:228) }\end{array}$ \\
\hline
\end{tabular}

In this translation, the translator described tayub as social dancing. Cultural equivalen procedure is used to translate tayub into social dancing.

\begin{tabular}{|l|l|l|}
\hline Activies and & Source Language & Target Language \\
\hline
\end{tabular}




\begin{tabular}{|l|l|l|}
\hline Procedures & & \\
\hline Bukak- Klambu & $\begin{array}{l}\text { Syarat terakhir yang } \\
\text { harus dipenuhi oleh } \\
\text { Srintil bernama bukak- } \\
\text { klambu . (Tohari, } \\
2003: 51 \text { ) }\end{array}$ & $\begin{array}{l}\text { The last ritual was called } \\
\text { bukak klambu - “opening } \\
\text { of the mosquito net." } \\
\text { (Lysloff, 2003:51) }\end{array}$ \\
& & \\
\hline
\end{tabular}

This translation used two procedures (couplet), naturalization and notes procedure. The translator used the original word in the SL and additional explanation into the TL.

\section{Religious Term}

\begin{tabular}{|c|c|c|}
\hline Religious Term & Source Language & Target Language \\
\hline Indang & $\begin{array}{l}\text { Bagaimana diajari, } \\
\text { seorang perawan tak } \\
\text { bisa menjadi ronggeng } \\
\text { kecuali roh indang } \\
\text { telah merasuk } \\
\text { tubuhnya. Indang } \\
\text { adalah semacam } \\
\text { wangsit yang } \\
\text { dimuliakan di dunia } \\
\text { peronggengan. (Tohari, } \\
\text { 2003:13) }\end{array}$ & $\begin{array}{l}\text { No matter how she was } \\
\text { trained, a young woman } \\
\text { could not become a } \\
\text { ronggeng dancer without } \\
\text { being possessed by the } \\
\text { indang spirit. In the world } \\
\text { of ronggeng, the indang was } \\
\text { revered as a kind of } \\
\text { supernatural } \\
\text { godmother.(Lysloff,2003:8) }\end{array}$ \\
\hline
\end{tabular}

The translator used naturalization and descriptive equivalent procedures since the TL retained the term indang by adding spirit.

\section{CONCLUSION}

Based on the analysis of literary works, Ronggeng Dukuh Paruk, a novel written by Ahmad Tohari and its Translation The Dancer, translated by Rene T.A. Lysloff, concludes follows. (1) literary work plays important role in doing literary translation research as it becomes the data source. (2) based on the analysis, it is found that there are 16 cultural terms and classified in 6 different categories (musical instruments, clothes, accessories, work and leisure, activities and procedures, and religious terms. In doing the translation, the translator uses 7 translation procedures (transference, naturalization, cultural equivalent, funciional equivalent, descriptive equivalent, couplets, and notes). Based on this research, it is suggested that students can have literary works, such as novel, short story, and poetry, as the source data in doing the research on literary translation. In researching in literary translation, students also have to master the translation 
theories well.

\section{ACKNOWLEDGEMENTS}

This research was partially supported by Universitas Nasional, Jakarta. I think Prof. Dr.Ernawati Sinaga, one of Rector's assistants who always supported me and provided insight and expertise that greatly assisted the research.

I thank the editors for your assistance with particular techniques, methodology, and also comments that greatly improved the manuscript.

I would also like to show my gratitute to the editor for sharing your pearls of wisdom with me during th course of this research, and I think "anonymous" reviewers for their so-called insights. I am also immensely grateful to the Editorin-Chief, Associate Editor, and Executive Editor for their comments on an earlier version of the manuscript, although any errors are my own and should not tarnish the reputations of these esteemed persons.

\section{REFERENCES}

Hapsari, Nurul Dian \& Retno Wulandari Setyaningsih. (2013) Cultural Words and The Translation in Twilight. Anglicist. Vol. 02, Number 02. 75-81.

Hasan, Bahaa-eddin Abulhassan. (2011). Literary Translation: Aspects of Pragmatic Meaning. UK: Cambridge Scholars publishing.

Krisnawati, Ni Luh Putu. (2017). The Procedure Applied in Translating Jargon in English, Parliamentary Debating into Indonesian. Lingual, Vol 8, Number 1, 34-39.

Kuswahono, Deny. (2019). Analysis on Translation of Cultural Terms in Dan Brown's The Da Vinci Code Novel from English into Indonesian. Thesis, Airlangga University.

Lysloff. R (2003). The Dancer. Jakarta : The Lontar Foundation.

Moleong, Lexy.J (2013). Metode Penelitian Kualitatif. Bandung: PT Remaja Rosdakarya

Meiliana, Sylvie (2019). The Role of Literary Work in Karo Community, Indonesia. International Journal of Innovation, Creativity and Change. Vol. 10, Issue 7, 2019.

Sundari, Hanna \& Rina Husnaini Febriyanti. (2016). Translation Techniques and Translation Competence in Translating Informative Text for Indonesian EFL Learners. Journal of English Language Teaching. Vol. 01, Number 01.

Tohari, Ahmad. (2003). Ronggeng Dukuh Paruk. Jakarta: Gramedia Pustaka Utama. Zang Yan. (2016). Approaches to Teaching Literary Translation. US-China Foreign Language. Vol 14, Number 14, 512-515. 